\title{
Serum concentration of beta-trace protein (BTP) as a potential biomarker of systemic sclerosis
}

\section{Stężenie białka śladowego beta (BTP) w surowicy jako potencjalny biomarker twardziny układowej}

Jakub Żółkiewicz, Anna Stochmal, Michał Zaremba, Lidia Rudnicka, Joanna Czuwara

Department of Dermatology, Medical University of Warsaw, Poland

Katedra i Klinika Dermatologiczna Warszawskiego Uniwersytetu Medycznego, Polska

\author{
CORRESPONDING AUTHOR/ \\ ADRES DO KORESPONDENCJI: \\ dr n. med. Joanna Czuwara \\ Katedra i Klinika Dermatologiczna \\ Warszawski Uniwersytet \\ Medyczny \\ ul. Koszykowa 82 A \\ 02-008 Warszawa \\ e-mail: jczuwara@yahoo.com
}

\begin{abstract}
Introduction. Systemic sclerosis is a connective tissue disease of unknown etiology characterized by endothelial cell injury, inflammation and fibrosis. Beta-trace protein (BTP) catalyzes conversion of prostaglandin $\mathrm{H} 2$ to prostaglandin D2. Prostaglandin D2 stimulates the vascular response by DP1 and allergic reactions by CRTH2.

Objective. To evaluate serum BTP in systemic sclerosis and correlate it with systemic sclerosis subtype, C-reactive protein, disease duration, skin fibrosis, and vascular and internal organ involvement.

Material and methods. Forty-six patients with systemic sclerosis and 30 healthy volunteers were included in the study. Clinical and laboratory data were collected including specific antibodies, interstitial lung disease, esophageal involvement, digital pitting scars, disease duration, Raynaud's phenomenon and modified Rodnan skin score. BTP levels were analyzed by ELISA. Statistical analysis was performed by $\chi^{2}$, Student's $t$-test and Mann-Whitney- $U$ test. Pearson and Spearman correlation analyses were used to establish variables' association. The significance threshold was set at $p<0.05$.
\end{abstract}

Results. Patients with systemic sclerosis had significantly higher serum BTP concentration in comparison to healthy controls at $p=0.0003$. No association between BTP levels and C-reactive protein, internal organ involvement, disease duration, autoantibodies and Raynaud's phenomenon onset was found. Patients who developed pitting scars and fingertip ulcerations had significantly higher BTP serum levels than those without these symptoms $(p=0.03)$.

Conclusions. Significantly elevated BTP in systemic sclerosis at $p<0.001$ may indicate the role of BTP in disease pathogenesis, since a BTP-dependent effect can be involved in three main features of systemic sclerosis: inflammation/autoimmunity, vasocontraction and fibrosis. Further studies with larger numbers of patients are required to fully establish the prognostic and diagnostic significance of BTP in systemic sclerosis.

\section{STRESZCZENIE}

Wprowadzenie. Twardzina układowa jest chorobą tkanki łącznej o nieznanej etiologii, charakteryzującą się uszkodzeniem komórek śród- 
błonka, stanem zapalnym i zmniejszoną ilością naczyń włosowatych. Białko śladowe beta (beta-trace protein - BTP) katalizuje konwersję prostaglandyny H2 do prostaglandyny D2. Prostaglandyna D2 oddziałuje na naczynia krwionośne przez receptor DP1 i wpływa na odpowiedź alergiczno-immunologiczną przez receptor CRTH2.

Cel pracy. Zbadanie stężenia BTP w surowicy pacjentów z twardziną układową i określenie zależności między BTP i podtypem twardziny układowej, białkiem ostrej fazy, czasem trwania choroby, włóknieniem skóry, zajęciem naczyń i narządów wewnętrznych.

Materiał i metody. Do badania włączono 46 pacjentów z twardziną układową i 30 zdrowych ochotników. Zebrano dane kliniczne i laboratoryjne $\mathrm{z}$ uwzględnieniem typów autoprzeciwciał, śródmiąższowej choroby płuc, zajęcia przełyku, blizenek na opuszkach palców rąk, czasu trwania choroby, obecności objawu Raynauda i stwardnienia skóry w ocenie wg zmodyfikowanej skali Rodnana. Stężenie BTP zmierzono metodą ELISA. Analizę statystyczną przeprowadzono za pomocą $\chi^{2}$, testu $t$-Studenta i testu $U$ Manna-Whitneya. Współczynniki korelacji Pearsona i Spearmana użyto do oceny zależności pomiędzy badanymi zmiennymi. Istotność statystyczna została ustalona na poziomie $p<0,05$.

Wyniki. U pacjentów z twardziną układową stwierdzono znacząco większe stężenie BTP $\mathrm{w}$ surowicy $\mathrm{w}$ porównaniu ze zdrową grupą kontrolną ( $p=0,0003)$. Nie wykazano związku między stężeniem BTP i białkiem ostrej fazy, zajęciem narządów wewnętrznych, czasem trwania choroby i objawu Raynauda oraz autoprzeciwciałami. Pacjenci z blizenkami i owrzodzeniami palców rąk mieli znacząco większe stężenie BTP w surowicy niż pacjenci bez tych objawów $(p=0,03)$.

Wnioski. Znacząco większe stężenie BTP u pacjentów z twardziną układową w porównaniu z osobami zdrowymi $(p<0,001)$ może świadczyć o jego roli w patogenezie choroby. BTP aktywuje procesy, które wpływają na trzy podstawowe zjawiska w twardzinie układowej: autoimmunizację, patologiczny skurcz naczyń i włóknienie. Potrzebne są dalsze badania w większej grupie pacjentów, aby określić znaczenie rokownicze i diagnostyczne BTP w twardzinie układowej.

Key words: beta-trace protein, prostaglandin D-synthase, systemic sclerosis, prostanoids, digital pits.

Słowa kluczowe: białko śladowe beta, syntaza prostaglandyny D, twardzina układowa, prostanoidy, blizenki na palcach rąk.

\section{INTRODUCTION}

Systemic sclerosis (SSc) is a chronic progressive connective tissue disease of unknown etiology that affects skin and internal organs such as lungs, kidneys, heart and gastrointestinal tract [1]. The early stage of the disease is characterized by endothelial cell injury, perivascular inflammation and reduction of capillary density leading to decreased capillary blood flow and severe tissue hypoxia which can clinically manifest as skin ulcers [2]. The hallmark of the late stages of SSc is tissue fibrosis which results from excessive production and accumulation of extracellular matrix (ECM) components around activated fibroblasts which have

\section{WPROWADZENIE}

Twardzina układowa (systemic sclerosis - SSc) jest przewlekłą, postępującą chorobą tkanki łącznej o nieznanej etiologii, która obejmuje skórę i narządy wewnętrzne, takie jak płuca, nerki, serce i przewód pokarmowy [1]. We wczesnym etapie choroba charakteryzuje się uszkodzeniem komórek śródbłonka, następnie zapaleniem okołonaczyniowym i zmniejszeniem gęstości naczyń włosowatych, co prowadzi do zmniejszenia przepływu krwi włośniczkowej i granicznego niedotlenienia tkanek objawiającego się owrzodzeniami skóry [2]. Cechą charakterystyczną późniejszego stadium SSc jest włóknienie tkanek w wyniku 
differentiated toward myofibroblasts with profibrotic and contraction properties. Microvascular injury and endothelial cell dysfunction which result in vascular damage and loss of capillaries are the earliest, and possible primary events in SSc [3].

Patients with SSc can be grouped into limited cutaneous systemic sclerosis (lcSSc) and diffuse cutaneous type (dcSSc) based on the extent of skin fibrosis. In lcSSc skin hardening is restricted to the fingers, distal extremities and face, whereas in dcSSc, the trunk and proximal extremities are affected [1]. In patients with lcSSc, Raynaud's phenomenon (RP) can precede skin involvement by months to years and this type is often associated with centromere-specific antibodies, whereas dcSSc is commonly associated with anti-topoisomerase I or RNA polymerase III specific antibodies [4].

Beta-trace protein (BTP), also known as lipocalin-type prostaglandin D2 synthase (L-PGDS), is a secretory protein belonging to the lipocalin protein family. BTP acts as prostaglandin isomerase catalyzing conversion of the prostanoid precursor prostaglandin $\mathrm{H} 2$ to prostaglandin D2 (PGD2). PGD2 can stimulate the vascular response by interaction with D prostanoid receptor (called DP1) and allergic reactions by a chemoattractant receptor-like molecule expressed on Th2 cells (CRTH2, also named DP2) [5]. DP1 receptor is expressed in endothelium but also on other cell types involved in SSc pathogenesis, e.g. bronchial epithelium, smooth muscle cells and fibroblasts. The role of the DP1 receptor remains obscure. Activation of the DP1 receptor increases levels of cAMP, resulting in vaso- and broncho-dilation; however, PGD2 has also been shown to cause blood vessel contraction in an endothelium-independent manner [6]. CRTH2 receptor was initially discovered on Th2 lymphocytes but it is also present on mast cells, monocytes, osteoblasts and eosinophils. The most prominent manifestations of CRTH2 activation are enhanced chemoattraction and increased production of Th2 cytokines such as IL-4 and IL-13 [5] with the established role in SSc pathogenesis due to profibrotic effects they demonstrate [1]. Clinical trials to inhibit both IL-4 and IL-13 are planned in SSc [7]. Additionally, PGD2 is produced by Th2, other lymphocyte populations and antigen-presenting cells, suggesting a modulatory role of PGD2 in the development of an antigen-specific immune system response. Overall, PGD2 elicits a pro-inflammatory effect, which has been already established in many allergic diseases [5, 8]. PGD2 is also released in significant amounts by endothelial cells, implying its role in vascular dilation [8] or the tissue injury/repair response [9].

A secondary product of BTP action, a prostaglandin derivative of PGD2, is 15d-PGJ2, which acts as nadmiernej produkcji i gromadzenia się składowych białkowych macierzy zewnątrzkomórkowej (extracellular matrix - ECM) wokół pobudzonych fibroblastów, zróżnicowanych w miofibroblasty o cechach profibrotycznych i właściwościach kurczliwości. Uraz mikronaczyń oraz nieprawidłowe funkcjonowanie komórek śródbłonka prowadzące do uszkodzenia naczyń i ich zaciskania to najprawdopodobniej najwcześniejsze i pierwotne zjawisko w patogenezie SSc [3].

Na podstawie stopnia zajęcia skóry SSc dzieli się na dwa zasadnicze typy - ograniczoną skórną (limited cutaneous $S S c-1 c S S c)$ i uogólnioną twardzinę układową (diffuse cutaneous SSc-dcSSc). W lcSSc stwardnienie skóry ograniczone jest do palców i dystalnych części kończyn oraz twarzy, podczas gdy w dcSSc występuje proksymalnie na tułowiu i na kończynach [1]. U pacjentów z lcSSc objaw Raynauda (Raynaud's phenomenon - RP) zazwyczaj wyprzedza zajęcie skóry o miesiące lub lata i podtyp ten jest często związany z przeciwciałami antycentromerowymi, podczas gdy dcSSc jest często związany z przeciwciałami przeciwko topoizomerazie I lub polimerazie III RNA [4].

Śladowe białko beta (beta-trace protein - BTP), nazywane również syntazą typu lipokaliny prostaglandyny D2 (lipocalin-type prostaglandin D2 synthase - L-PGDS), jest białkiem wydzielniczym należącym do rodziny białek lipokalinowych. BTP działa jak izomeraza prostaglandynowa i katalizuje konwersję prekursora prostanoidu - prostaglandyny $\mathrm{H} 2$ - do prostaglandyny D2 (PGD2). PGD2 ma dwukierunkowe działanie: może stymulować odpowiedź naczyniową poprzez interakcję z receptorem prostanoidowym D (zwanym DP1) i reakcje alergiczne przez cząsteczkę podobna do receptora chemoatraktantu występującą na komórkach Th2 (chemoattractant receptor-like molecule - CRTH2, nazwaną również DP2) [5]. Receptor DP1 obecny jest na śródbłonku naczyń, ale także na innych typach komórek zaangażowanych w patogenezę SSc, np. nabłonku oskrzeli, komórkach mięśni gładkich i fibroblastach. Rola receptora DP1 nie jest do końca poznana. Aktywacja DP1 zwiększa poziom cAMP, co prowadzi do rozkurczu naczyń i oskrzeli. Stwierdzono także, że PGD2 powoduje skurcz naczyń krwionośnych w sposób niezależny od komórek śródbłonka [6]. Receptor CRTH2 początkowo stwierdzono na limfocytach Th2, a później na komórkach tucznych, monocytach, osteoblastach i eozynofilach. Najczęstszymi objawami stymulacji CRTH2 są zwiększona chemoatrakcja komórek zapalnych i zwiększona produkcja cytokin Th2, takich jak IL-4 i IL-13 [5], których rola jest także znana w patogenezie SSc w związku z ich stymulującym wpływem na włóknienie [1]. Planowane są obecnie badania kliniczne dotyczące SSc z zahamowaniem obydwu IL-4 i IL-13 [7]. Dodatkowo PGD2 jest produkowany przez Th2 i inne populacje limfocytów oraz komórki 
a ligand of peroxisome proliferator-activated receptor $\gamma$ (PPAR- $\gamma$ ) with well-known anti-inflammatory properties. PPAR- $\gamma$ activation by $15 \mathrm{~d}-\mathrm{PGJ} 2$ showed a broad inhibitory effect on eosinophil-mediated diseases by decreasing eosinophil infiltration, cytokines IL-5 and IL-33 expression and the amount of IgE [10].

BTP was originally found in cerebrospinal fluid (CSF) [9], and subsequently was discovered in other body fluids such as blood and urine [11]. An elevated level of L-PGDS in CSF has been shown in spontaneous intracranial hypotension caused by CSF leakage [12]. It has been suggested that low pressure and hypovolemia of CSF increase the secretion of L-PGDS into CSF. L-PGDS is also excreted by kidneys and in renal diseases BTP is increased in the serum and urine [13]. Due to its stability, constitutive synthesis, and biological half-life of 1.2 hours, it has been used as a potential biomarker reflecting kidney function in the serum [14]. Indeed, increased levels of BTP in serum and urine correlate with renal failure or chronic renal disease progression $[11,13]$.

\section{OBJECTIVE}

Since vasculopathy presents as a major clinical problem in patients with SSc in whom vascular contraction is aggravated whilst relaxation is impaired, the aim of the study was to evaluate serum BTP in SSc and correlate it with SSc subtype, high-sensitivity C-reactive protein (hs-CRP), disease duration, and vascular and internal organ involvement.

\section{MATERIAL AND METHODS}

A cohort of 46 patients diagnosed with SSc (43 women and 3 men) and 30 healthy volunteers (26 women and 4 men) were included and recruited in the study to assess BTP concentration in their sera. Both subsets were age, sex, body mass index (BMI) and hs-CRP matched as presented in table 1. All patients with SSc fulfilled the American College of Rheumatology/European League Against Rheumatism 2013 classification criteria [15] and were divided into two groups according to the disease subtype: limited cutaneous SSc (lcSSc, $n=34$ ) and diffuse cutaneous SSc (dcSSc, $n=12$ ). Clinical and laboratory data were collected at the time of blood sampling and included the presence of: specific antibodies, interstitial lung disease, esophageal involvement, digital pitting scars and ulcerations, duration of the disease, duration of Raynaud's phenomenon, assessment of modified Rodnan skin score (mRSS). Antibodies in our patient cohort group were detected and specified as described in our previous paper [4]. In 37 (80.43\%) patients two or more antibodies coexisted in the immunoblot detection method. Twenty-one patients out prezentujące antygen, co sugeruje modulującą rolę PGD2 w rozwoju antygenowo swoistej odpowiedzi układu immunologicznego. Podsumowując - PGD2 ma działanie prozapalne, które potwierdzono w wielu chorobach alergicznych $[5,8]$. PGD2 jest również uwalniany w znacznych ilościach przez komórki śródbłonka, co sugeruje jego rolę w rozszerzaniu naczyń [8], w odpowiedzi na uszkodzenie lub naprawę tkanki [9].

Wtórnym produktem aktywności BTP jest prostaglandynowa pochodna PGD2, tj. 15d-PGJ2, która jest ligandem receptora $\gamma$ aktywowanego przez proliferatory peroksysomów (peroxisome proliferator-activated receptor $\gamma$ - PPAR- $\gamma$ ) o dobrze poznanych właściwościach przeciwzapalnych. Aktywacja PPAR- $\gamma$ przez 15d-PGJ2 ma wielokierunkowe działanie ograniczające choroby indukowane eozynofilami poprzez zmniejszenie nacieku z eozynofilów, zmniejszenie ekspresji cytokin IL-5 i IL-33 oraz ilości IgE [10].

Pierwotnie BTP stwierdzono w płynie mózgowo-rdzeniowym (cerebrospinal fluid - CSF) [9], a następnie w innych płynach ustrojowych, takich jak krew i mocz [11]. Podwyższony poziom L-PGDS w CSF wykazano w samoistnym niedociśnieniu śródczaszkowym spowodowanym wyciekiem płynu mózgowo-rdzeniowego [12]. Uważa się, wydzielanie L-PGDS do CSF zwiększają niskie ciśnienie i hipowolemia CSF. L-PGDS jest również wydalany przez nerki, a w chorobach nerek wzrasta jego ilość w surowicy i moczu [13]. W związku ze stabilnością cząsteczki, konstytutywną ekspresją i biologicznym czasem półtrwania wynoszącym 1,2 godziny BTP jest wykorzystywana jako potencjalny biomarker odzwierciedlający funkcję nerek [14]. Zwiększone ilości BTP w surowicy i moczu korelują z niewydolnością nerek i progresją przewlekłej choroby nerek [11, 13].

\section{CEL PRACY}

Zaburzenia naczyniowe stanowią poważny problem kliniczny u pacjentów z SSc, a dominującą cechą jest nasilony skurcz naczyń kosztem upośledzonej relaksacji, dlatego celem badania była ocena stężenia BTP w surowicy w SSc i jego korelacji z podtypem choroby, białkiem ostrej fazy, czasem trwania choroby, zajęciem naczyń i narządów wewnętrznych.

\section{MATERIA $~ I$ METODY}

Do badania zrekrutowano i włączono 46 pacjentów z SSc (43 kobiety i 3 mężczyzn) i 30 zdrowych ochotników (26 kobiet i 4 mężczyzn) w celu oceny stężenia BTP w surowicy. Obie grupy nie różniły się pod względem wieku, płci, wskaźnika masy ciała (body mass index - BMI) i stężenia białka ostrej fazy (CRP) (tab. 1). Wszyscy pacjenci spełniali kryteria 
Table I. Demographic data for BTP group, including healthy controls and patients with systemic sclerosis (SSc)

Tabela I. Dane demograficzne grupy kontrolnej i pacjentów z twardziną układową (SSc) w badaniu BTP

\begin{tabular}{|c|c|c|c|}
\hline Parameter/Parametr & $\begin{array}{l}\text { Controls/Kontrola } \\
\qquad(n=30)\end{array}$ & $\begin{array}{c}\text { SSc } \\
(n=46)\end{array}$ & $\begin{array}{l}\text { P-value/ } \\
\text { Wartość } p\end{array}$ \\
\hline Age, mean \pm SD [years]Miek, średnia \pm OS [lata] & $49.33 \pm 14.1$ & $55.6 \pm 12.98$ & 0.05 \\
\hline Females/Kobiety, n (\%) & $26(86.67)$ & $43(93.48)$ & 0.55 \\
\hline $\mathrm{BMI}$, mean $\pm \mathrm{SD} / \mathrm{BMI}$, średnia $\pm \mathrm{OS}\left[\mathrm{kg} / \mathrm{m}^{2}\right]$ & $24.13 \pm 2.92$ & $23.88 \pm 3.26$ & 0.74 \\
\hline $\begin{array}{l}\text { Disease duration, mean } \pm \text { SD [years]/Czas trwania choroby, } \\
\text { średnia } \pm \text { OS [lata] }\end{array}$ & $\mathrm{N} / \mathrm{A}$ & $7.8 \pm 5.64$ & $\mathrm{~N} / \mathrm{A}$ \\
\hline $\begin{array}{l}\text { Time from onset of Raynaud's phenomenon, mean } \pm \text { SD [years]/ } \\
\text { Czas od pojawienia się objawu Raynauda, średnia } \pm \text { OS [lata] }\end{array}$ & $\mathrm{N} / \mathrm{A}$ & $13.94 \pm 9.12$ & $\mathrm{~N} / \mathrm{A}$ \\
\hline mRSS, mean $\pm \mathrm{SD} / \mathrm{mRSS}$, średnia \pm OS & $\mathrm{N} / \mathrm{A}$ & $7.87 \pm 5.48$ & $\mathrm{~N} / \mathrm{A}$ \\
\hline $\begin{array}{l}\text { Correlation between BTP and disease duration/Korelacja między BTP } \\
\text { a czasem trwania choroby }\end{array}$ & $\mathrm{N} / \mathrm{A}$ & -0.11 & $>0.05$ \\
\hline $\begin{array}{l}\text { Correlation between BTP and mRSS/Korelacja między BTP } \\
\text { a stwardnieniami skóry (mRSS) }\end{array}$ & $\mathrm{N} / \mathrm{A}$ & 0.03 & $>0.05$ \\
\hline $\begin{array}{l}\text { Correlation between BTP and time from onset of Raynaud's } \\
\text { phenomenon/Korelacja między BTP a czasem trwania objawu Raynauda }\end{array}$ & $\mathrm{N} / \mathrm{A}$ & 0.22 & $>0.05$ \\
\hline $\begin{array}{l}\text { Serum BTP level, median (range) [ng/ml]/Stężenie BTP w surowicy, } \\
\text { mediana (zakres wartości) }[\mathrm{ng} / \mathrm{ml}]\end{array}$ & $7 \mid 4(472-2125)$ & II $52(648-2705)$ & 0.0003 \\
\hline $\begin{array}{l}\text { hs-CRP level, median (range) [mg/l]/Stężenie hs-CRP, mediana } \\
\text { (zakres wartości) [mg/] }\end{array}$ & $2.45(0.25-60.2)$ & $1.6(0.1-2.8)$ & 0.1 \\
\hline
\end{tabular}

of 46 (45.65\%) were anti-topoisomerase I positive (anti-TOPO I), 22 out of 46 were both anti-centromere A and B positive (ACA) (47.83\%), 13 patients had antibodies against RP155 (anti-RNA polymerase III) $(28.26 \%), 8(17.39 \%)$ patients were positive for anti-RP11. Some other types of antibodies coexisting with the aforementioned ones are presented in table 2 with the percentage of incidence.

All patients with SSc were hospitalized in our department in order to receive rheological intravenous treatment including sulodexide or alprostadil (PGE1) and to perform routine laboratory and imaging diagnostic tests. In all patients the acute coronary syn- rozpoznania choroby wg klasyfikacji American College of Rheumatology/European League Against Rheumatism 2013 [15]. Podzielono ich na dwie grupy wg podtypu SSc: lcSSc $(n=34)$ i dcSSc $(n=12)$. Przed pobraniem krwi w celu oceny stężenia BTP zebrano dane kliniczne i laboratoryjne obejmujące obecność specyficznych przeciwciał, śródmiąższowej choroby płuc, zajęcia przełyku, blizenek i owrzodzeń na palcach rąk, czasu trwania choroby, czasu trwania objawu Raynauda, ocenę włóknienia skóry wg zmodyfikowanej skali Rodnana (mRSS). Przeciwciała wykryto i zidentyfikowano w sposób opisany we wcześniejszej publikacji [4]. U 37 (80,43\%) pacjentów

Table 2. Antinuclear antibodies detected with immunoblotting in the study group of 46 patients with systemic sclerosis

Tabela 2. Przeciwciała przeciwjądrowe określone metodą immunoblot u badanych 46 pacjentów z twardziną układową

\begin{tabular}{lccc} 
Antibody type/Typ przeciwciała & No. of patients /Liczba pacjentów $(N=46)$ & Incidence/Odsetek pacjentów (\%) \\
Anti-TOPO I (Scl-70) & 21 & 45.65 \\
\hline Anti-Centromere A & 22 & 47.83 \\
\hline Anti-Centromere B & 22 & 47.83 \\
\hline Anti-RPII & 8 & 17.39 \\
\hline Anti-RPI55 & 13 & 28.26 \\
\hline Anti-Fibrillarin & 1 & 2.17 \\
\hline Anti-NOR90 & 2 & 4.35 \\
\hline Anti-Th/To & 1 & 2.17 \\
\hline Anti-PM-Scl75 & 5 & 10.87 \\
\hline Anti-Ku & 3 & 6.52 \\
\hline Anti-Ro-52 & 9 & 19.57 \\
\hline
\end{tabular}


drome was excluded based on electrocardiographs (ECG) or echocardiography before the introduction of rheological intravenous treatment.

Subjects who had a history of at least one of the following criteria were excluded from the study: acute or chronic renal failure, diagnosis of internal cancer, stroke, myocardial infarction, infection, diabetes, pregnancy, paroxysmal atrial fibrillation, allergic disorders (e.g. asthma, contact dermatitis, atopic dermatitis), autoimmune and rheumatic disorders other than SSc (e.g. systemic lupus erythematosus, pemphigus, pemphigoid, ulcerative colitis, Crohn's disease).

\section{Clinical parameters}

Clinical examination of each patient was carefully performed by an independent dermatologist from our clinic. Severity of skin involvement was evaluated using the mRSS. The BMI was calculated as weight/square of height $\left(\mathrm{kg} / \mathrm{m}^{2}\right)$. The duration of SSc was estimated by the first noticeable skin thickening of the fingers described as puffy fingers or sclerodactyly. Duration of the disease, Raynaud's phenomenon in years, and BMI are presented in tables 1 and 3 .

Interstitial lung disease (ILD) was defined by the presence of lung fibrosis detected on high-resolution computed tomography (HRCT) with spirometry and diffusing lung capacity for carbon monoxide (DLCO) results confirming restriction changes. The presence of esophageal involvement was considered based on reported symptoms regarding difficulties with swallowing, confirmed by the typical outline of this disorder in X-ray barium swallow study or esophageal scintigraphy (e.g. dilution or dysmotility of esophagus). Radiological images were assessed by experi- metodą immunoblot wykazano współwystępowanie dwóch lub więcej autoprzeciwciał. Stwierdzono następującą częstość występowania przeciwciał: anty-TOPO I u $21(45,65 \%)$ pacjentów, antycentromerowe (ACA) A i B u 22 (47,83\%), przeciwko polimerazie III RNA (RP155) u 13 (28,26\%), anty-RP11 u 8 (17,39\%). Inne typy przeciwciał i częstość ich występowania przedstawiono w tabeli 2.

Wszyscy pacjenci byli hospitalizowani w celu dożylnego leczenia reologicznego sulodeksydem lub alprostadylem (PGE1) i wykonania rutynowych badań laboratoryjnych i obrazowych. U wszystkich wykluczono ostry zespół wieńcowy na podstawie elektrokardiogramów (EKG) lub echokardiografii przed podaniem leczenia reologicznego.

$\mathrm{Z}$ badania wykluczono osoby mające $\mathrm{w}$ wywiadzie co najmniej jedną z następujących chorób: ostra lub przewlekła niewydolność nerek, nowotwór narządów wewnętrznych, udar, zawał mięśnia sercowego, aktywne zakażenie, cukrzyca, napadowe migotanie przedsionków, choroby alergiczne (np. astma, kontaktowe zapalenie skóry, atopowe zapalenie skóry), zaburzenia autoimmunologiczne i reumatyczne inne niż SSc (np. toczeń rumieniowaty układowy, pęcherzyca, pemfigoid, wrzodziejące zapalenie jelita grubego, choroba Leśniowskiego-Crohna), a także kobiety w ciąży.

\section{Objawy kliniczne}

Każdego pacjenta badał niezależny dermatolog z kliniki. Stopień zajęcia skóry oceniano za pomocą mRSS. Wskaźnik masy ciała obliczano jako stosunek masy do kwadratu wzrostu $\left(\mathrm{kg} / \mathrm{m}^{2}\right)$. Czas trwania SSc wyznaczono od momentu pierwszego zauważalnego pogrubienia i obrzęku palców rąk (sklerodaktylia). Czas trwania choroby i objawu Raynauda w latach, mRSS oraz BMI przedstawiono w tabelach 1 i 3.

Table 3. Demographic data, clinical characteristics and inflammatory parameters in disease subtypes and skin involvement in limited cutaneous systemic sclerosis (IcSSc) and diffuse cutaneous systemic sclerosis (dcSSc) in analyzed BTP group of patients

Tabela 3. Dane demograficzne pacjentów w badaniu BTP. Charakterystyka kliniczna, parametry zapalne i zajęcie skóry w twardzinie układowej ograniczonej (IcSSc) i uogólnionej (dcSSc)

\begin{tabular}{|c|c|c|c|}
\hline Parameter/Parametr & $\begin{array}{c}\text { IcSSc } \\
(n=34)\end{array}$ & $\begin{array}{l}\text { dcSSc } \\
(n=12)\end{array}$ & $\begin{array}{l}\text { P-value/ } \\
\text { Wartość } p\end{array}$ \\
\hline Age, mean \pm SD [years]/Wiek, średnia \pm OS [lata] & $58.03 \pm 12.46$ & $48.75 \pm 12.4$ & 0.03 \\
\hline Females/Kobiety, n (\%) & $32(94.12)$ & II (91.67) & 0.7 \\
\hline BMI, median (range) $\left[\mathrm{kg} / \mathrm{m}^{2}\right] / \mathrm{BMI}$, mediana (zakres) $\left[\mathrm{kg} / \mathrm{m}^{2}\right]$ & $23.85(19.25-32.8)$ & $22.35(17.6-28)$ & 0.02 \\
\hline $\begin{array}{l}\text { Disease duration, median (range) [years]/Czas trwania choroby, } \\
\text { mediana (zakres) [lata] }\end{array}$ & $5.5(|-2|)$ & $9(1-24)$ & 0.26 \\
\hline $\begin{array}{l}\text { Duration of Raynaud's phenomenon, median (range) [years]/ } \\
\text { Czas trwania objawu Raynauda, mediana (zakres) [lata] }\end{array}$ & $12.5(\mid-40)$ & $12(4-25)$ & 0.49 \\
\hline mRSS, median (range)/mRSS, mediana (zakres) & $5(3-10)$ & $15(6-26)$ & 0.0001 \\
\hline $\begin{array}{l}\text { Serum BTP level, median (range) }[\mathrm{ng} / \mathrm{ml}] / \text { Stężenie BTP w surowicy, } \\
\text { mediana (zakres) }[\mathrm{ng} / \mathrm{ml}]\end{array}$ & 1115 (673-2705) & $1214(648-2173)$ & 0.83 \\
\hline hs-CRP level, mean \pm SD [mg/l]/Stężenie hs-CRP, średnia \pm OS [mg/l] & $1.53 \pm 0.6$ & $1.77 \pm 0.43$ & 0.22 \\
\hline
\end{tabular}

BMI - body mass index, mRSS - modified Rodnan skin score, hs-CRP - high-sensitivity C-reactive protein.

BMI - wskaźnik masy ciała, mRSS - zmodyfikowana skala Rodnana, hs-CRP - wysoko swoiste białko ostrej fazy. 
Table 4. Comparison of BTP levels [ng/ml] between patients with and without internal organs and vascular hand involvement estimated by finger tip ulcerations or presence of pitting scars

Tabela 4. Porównanie stężeń BTP [ng/ml] u pacjentów z zajęciem i bez zajęcia narządów wewnętrznych oraz z objawami naczyniowymi rąk ocenianymi przez obecność owrzodzeń na palcach rąk lub zanikowych blizenek

\begin{tabular}{|c|c|c|c|}
\hline \multirow[t]{2}{*}{ Clinical symptoms/Objawy kliniczne } & \multicolumn{3}{|c|}{ Comparison/Porównanie } \\
\hline & $\begin{array}{l}\text { With symptom/ } \\
\text { Z objawami }\end{array}$ & $\begin{array}{l}\text { Without symptom/ } \\
\text { Bez objawów }\end{array}$ & $\begin{array}{l}\text { P-value/ } \\
\text { Wartość } p\end{array}$ \\
\hline Interstitial lung disease/Śródmiąższowa choroba płuc & $\begin{array}{c}N=25 \\
\mid 157(648-2705)\end{array}$ & $\begin{array}{c}N=21 \\
\mid 146(783-1915)\end{array}$ & 0.91 \\
\hline Esophagus involvement/Zajęcie przełyku & $\begin{array}{c}N=16 \\
981(648-1938)\end{array}$ & $\begin{array}{c}N=30 \\
\mid 160(673-2705)\end{array}$ & 0.36 \\
\hline $\begin{array}{l}\text { Presence of finger tip ulcerations or pitting scars/Obecność } \\
\text { owrzodzeń na palcach rąk lub zanikowych punkcikowych blizenek }\end{array}$ & $\begin{array}{c}N=15 \\
|421.2 \pm 573 .|\end{array}$ & $\begin{array}{c}N=3 \mid \\
\mid 130.2 \pm 303\end{array}$ & 0.03 \\
\hline
\end{tabular}

enced radiologists from the radiology department. In order to assess renal function, estimated glomerular filtration rate (eGFR), blood urea nitrogen and a history of kidney diseases or transplantation were carefully monitored. Vascular hand involvement was estimated based on clinical signs such as presence of fingertip ulcers or pitting scars. The number of SSc patients with or without organ and hand involvement is summarized in table 4.

\section{Serological methods}

Blood samples were collected during routine blood donation in the morning after the overnight fast. Samples were centrifuged within 30 minutes at room temperature and obtained sera were stored in aliquots at $-70^{\circ} \mathrm{C}$ until processing. Circulating serum levels of BTP (Cayman Chemical, Ann Arbor, Cat. No. 10007684) were analyzed by enzyme-linked immunosorbent assay (ELISA) according to manufacturer instruction. Standards and samples were measured in duplicates and the mean values were calculated to express serum concentrations of BTP protein in $\mathrm{ng} / \mathrm{ml}$.

\section{Ethics}

The study was conducted in compliance with the Declaration of Helsinki and was approved by the Ethics Committee of the Medical University of Warsaw (No. KB/66/2018). Informed consent was obtained from all participants included in the study.

\section{Statistical analysis}

All statistical analyses were performed using Statistica 13.3 (StatSoft/TIBCO, Cracow, Poland). Each parameter was assessed for normality with the Shapiro-Wilk test. Subgroup heterogeneity and dichotomous data were tested with the $\chi^{2}$ test. Student's $t$-test was used to analyze data with normal distribution and the Mann-Whitney- $U$ test was used for the comparison of non-parametric continuous
Śródmiąższowa choroba płuc (interstitial lung disease - ILD) została zdefiniowana jako obecność zwłóknienia płuc $\mathrm{w}$ tomografii komputerowej o wysokiej rozdzielczości (high-resolution computed tomography - HRCT) z wynikami spirometrii i dyfuzyjnej pojemności płuc dla tlenku węgla (diffusing lung capacity for carbon monoxide - DLCO) potwierdzającymi zmiany restrykcyjne. Zajęcie przełyku rozpoznawano na podstawie podawanych trudności w połykaniu, potwierdzonych typowym zarysem przełyku w badaniu rentgenowskim z papką barytową lub w scyntygrafii przełyku (poszerzenie przełyku lub zaburzenie motoryki). Obrazy radiologiczne były interpretowane przez doświadczonych radiologów. W celu oceny czynności nerek wyznaczono szacunkowy współczynnik filtracji kłębuszkowej (estimated glomerular filtration rate eGFR), azot mocznikowy we krwi oraz zebrano wywiad w kierunku chorób nerek lub przeszczepu nerki. Zmiany naczyniowe rąk oceniono na podstawie obecności owrzodzeń lub blizenek na palcach rąk. Liczbę pacjentów z SSc z zajęciem lub bez zajęcia narządów i objawami naczyniowymi przedstawiono w tabeli 4 .

\section{Metody serologiczne}

Próbki krwi pozyskiwano podczas rutynowego pobrania krwi rano na czczo. Próbki wirowano przez 30 minut w temperaturze pokojowej i otrzymane surowice przechowywano $\mathrm{w}$ porcjach $\mathrm{w}$ temperaturze $-70^{\circ} \mathrm{C}$ do momentu wykorzystania. Krążący w surowicy BTP analizowano testem immunoenzymatycznym (ELISA) (Cayman Chemical, Ann Arbor, nr kat. 10007684) wg instrukcji producenta. Kontrole standardowe i próbki mierzono w dwóch powtórzeniach i obliczano średnie wartości stężeń BTP w ng/ml.

\section{Etyka badania}

Badanie zostało przeprowadzone zgodnie z Deklaracją Helsińską i zatwierdzone przez Komisję Bioetyczną Warszawskiego Uniwersytetu Medycznego (nr KB/66/2018). Wszyscy uczestnicy wyrazili świadomą zgodę na udział w badaniu. 


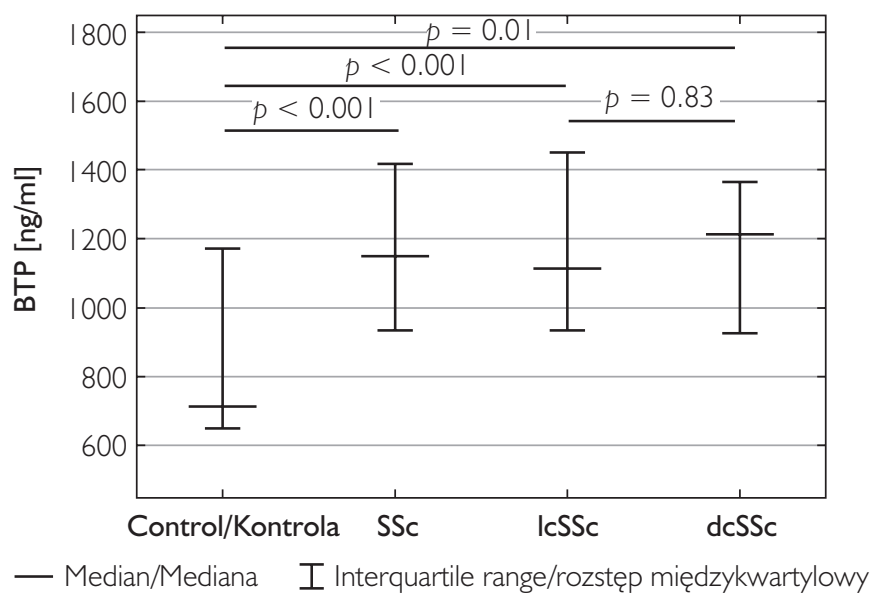

Figure I. BTP concentration in SSc group is significantly elevated in comparison to healthy control $(p<0.00 \mathrm{I})$. The patient group was additionally divided into limited cutaneous SSc (ICSSc) and diffuse cutaneous SSc (dcSSc) subsets. There is no significant difference between the mean BTP in IcSSc and dcSSc, but the difference between serum BTP concentration in healthy controls and IcSSc has shown higher significance $(p<0.00 \mathrm{I})$ than between healthy controls and dcSSc $(p=0.0 \mathrm{I})$

Rycina I. Stężenie BTP jest istotnie statystycznie wyższe u pacjentów z SSc w porównaniu ze zdrową kontrolą $(p<0.00 \mathrm{I})$. W grupie pacjentów podzielonej dodatkowo na twardzinę ograniczoną (IcSSc) i uogólnioną (dcSSc) nie wykazano różnic w stężeniach BTP między tymi podtypami SSc. Różnica stężeń BTP pomiędzy grupą zdrową i pacjentami z lcSSc wykazała większą istotność statystyczną $(p<0,00 \mathrm{I})$ niż z pacjentami z dcSSc $(p=0,0 \mathrm{I})$

variables. Pearson and Spearman correlation analyses were used to measure the association between variables. $P$-values $<0.05$ were rated as statistically significant.

\section{RESULTS}

Demographic characteristics of patients and controls are presented in table 1 . There was no statistically significant difference between the two groups in terms of sex and BMI ( $p>0.05)$. The mean age in patients with SSc was higher and reached 55.6 \pm 12.98 years in comparison to healthy controls with a mean age of $49.33 \pm 14.1$. The difference was borderline significant at $p=0.05$. Patients with SSc had significantly higher serum BTP concentration in comparison to healthy controls $(p=0.0003)$ and this significance can't be explained by age difference only (fig. 1). No associations between BTP levels and disease duration (either early or late SSc, which was arbitrarily defined as shorter or longer than 3 years, respectively), duration of Raynaud's phenomenon, or hs-CRP level were found. Moreover, BTP concentration did not correlate with skin fibrosis extent estimated by mRSS.

When the patient group was divided into limited SSc (lcSSc) and diffuse SSc (dcSSc) types, a difference in mean age was noted between the two subsets, with the older group being lcSSc $(p=0.03)$. The lowest BMI was established in diffuse SSc at $p=0.02$ what results from adipose tissue atrophy described in SSc [15] with significantly elevated mRSS in dcSSc $(p=0.0001)$, in comparison to lcSSc (table 3).

\section{Analiza statystyczna}

Wszystkie analizy przeprowadzono za pomocą programu Statistica 13.3 (StatSoft/TIBCO, Kraków, Polska). Do oceny normalności rozkładu zmiennych użyto testu Shapiro-Wilka. Niejednorodność podgrup została zbadana testem $\chi^{2}$. Test $t$-Studenta wykorzystano do analizy danych z rozkładem normalnym, a test $U$ Manna-Whitneya zastosowano do porównania zmiennych nieparametrycznych. Do oceny zależności pomiędzy zmiennymi wykorzystano analizę korelacji Pearsona i Spearmana. Istotność statystyczna dla wszystkich obliczeń została ustalona na poziomie $p<0,05$.

\section{WYNIKI}

Charakterystyka demograficzna pacjentów i zdrowej kontroli została przedstawiona w tabeli 1 . Nie stwierdzono różnic między grupami pod względem płci i BMI $(p>0,05)$. Średni wiek pacjentów z SSc był wyższy w porównaniu ze zdrową kontrolą - 55,6 $\pm 2,98$ roku vs 49,33 $\pm 14,1$ roku, z różnicą na granicy istotności $p=0,05$. Pacjenci z SSc mieli istotnie większe stężenie BTP $\mathrm{w}$ surowicy $\mathrm{w}$ porównaniu ze zdrową kontrolą $(p=0,0003)$, czego nie można wytłumaczyć tylko różnicą wieku (ryc. 1). Nie stwierdzono zależności między stężeniem BTP a czasem trwania choroby (wczesna lub późna SSc, umownie określone jako krótsze lub dłuższe od 3 lat), czasem trwania objawu Raynauda i stężeniem hs-CRP. Ponadto stężenie BTP nie korelowało ze stopniem zajęcia skóry ocenionym mRSS.

Po podzieleniu pacjentów na grupy z lcSSc i z dcSSc stwierdzono różnicę dotyczącą średniego 
No other differences were found between lcSSc and dcSSc groups. BTP mean concentration obtained in lcSSc was significantly higher in comparison to healthy controls $(p<0.001)$. The difference in BTP level between the dcSSc group and controls was smaller $(p=0.01)$ (fig. 1). Prevalence of ILD and esophagus involvement with BTP concentration did not show any correlation and is presented in table 4. Patients who developed pitting scars and had fingertip ulcerations had a significantly higher BTP serum level than those without this symptom $(p=0.03)$.

\section{DISCUSSION}

Lipocalin-type prostaglandin D2-synthase, also known as beta-trace protein (BTP), is a low molecular weight protein of 168 amino acids modified by a post-translational process of $\mathrm{N}$-glycosylation forming different isoforms, ranging from 23 to $29 \mathrm{kDa}$. BTP primarily was isolated from cerebrospinal fluid and later was widely detected in different tissues and body fluids [9]. The concentration of BTP is high in sites which are undergoing inflammatory processes or, in the case of the brain, suffering from trauma. It is unsolved whether BTP is involved in the repair mechanism of damaged tissue, or may be released from destroyed tissue. BTP has been suggested as a reliable serum marker for eGFR [14] and in cases of high levels in urine, it can serve as a predictor of early renal dysfunction or diabetic nephropathy [11]. BTP urine levels show a significant correlation with tubular damage and the magnitude of renal impairment in chronic kidney disease [13]. In our study, elevated serum BTP in SSc did not result from kidney disease, since patients selected for the study were not diagnosed either with acute or chronic renal disease, and patients' GFRs were within the normal range.

BTP is not only a marker of brain trauma or renal insufficiency. The biological function of BTP is to catalyze conversion of the prostanoid precursor prostaglandin $\mathrm{H} 2$ to prostaglandin D2 (PGD2) and its metabolite 15-deoxy- $\Delta 12,14$-prostaglandin J2 (15d-PGJ2), which regulate the inflammatory response and extracellular matrix synthesis. It has been shown in a mouse model that L-PGDS-derived PGD2 contributes to the progression of renal fibrosis via CRTH2-mediated activation on Th2 lymphocytes $[16,17]$ and L-PGDS is synthesized by tubular epithelium. Blocking the activation of CRTH2 induced by PGD2 or ablation of IL-4 and IL-13 ameliorated renal fibrosis. Also, both L-PGDS-knockout and CRTH2-knockout mice exhibited less renal fibrosis, reduced infiltration of Th2 lymphocytes into the kidney cortex, and decreased production of profibrotic cytokines such as IL-4 and IL-13 [17]. wieku. Pacjenci z lcSSc byli starsi $(p=0,03)$. Najniższy średni BMI mieli pacjenci z dcSSc $(p=0,02)$, co wynika z zaniku tkanki tłuszczowej w SSc [15]. W tej grupie mRSS był istotnie wyższy $\mathrm{w}$ porównaniu $\mathrm{z}$ grupa $\mathrm{z}$ lsSSc $(p=0,0001)$ (tab. 3).

Nie wykazano innych różnic między grupami $\mathrm{z}$ lcSSc i dcSSc. Średnie stężenie BTP $\mathrm{w}$ grupie z lcSSc było istotnie wyższe $\mathrm{w}$ porównaniu ze zdrową kontrolą $(p<0,001)$. Różnica stężeń BTP między grupą z dcSSc a grupą kontrolną była mniejsza $(p=0,01)$ (ryc. 1). Częstość występowania ILD i zajęcie przełyku nie wykazały korelacji ze stężeniem BTP (tab. 4). Pacjenci z blizenkami na opuszkach lub owrzodzeniami palców rąk mieli znacząco większe stężenie BTP w surowicy niż osoby bez tego objawu $(p=0,03)$.

\section{OMÓWIENIE}

Syntaza prostaglandyny D2 typu lipokaliny, znana również jako BTP, jest białkiem o małej masie cząsteczkowej złożonym ze 168 aminokwasów, modyfikowanym przez potranslacyjny proces N-glikozylacji do różnej wielkości izoform BTP od 23 do $29 \mathrm{kDa}$. BTP po raz pierwszy wyizolowano z płynu mózgowo-rdzeniowego, a późnej wykryto jego powszechne występowanie w różnych tkankach i płynach ustrojowych [9]. Stężenie BTP jest duże w miejscach procesów zapalnych lub w przypadku tkanki mózgowej po urazie. Nie wiadomo, czy BTP bierze udział w mechanizmie naprawy uszkodzonej tkanki, czy jest z niej uwalniany. Sugerowano, że BTP w surowicy jest wiarygodnym wskaźnikiem do oceny eGFR [14], a w przypadku wysokiego poziomu w moczu może służyć jako predyktor wczesnej niewydolności nerek lub nefropatii cukrzycowej [11]. Poziom BTP w moczu wykazuje znamienną korelację z uszkodzeniem kanalików nerkowych i nasileniem zaburzeń czynności nerek w przewlekłej chorobie nerek [13]. W naszym badaniu zwiększone stężenie BTP $\mathrm{w}$ surowicy w SSc nie wynikało $\mathrm{z}$ choroby nerek w związku z selekcją pacjentów bez ostrej lub przewlekłej choroby nerek i z prawidłowym GFR.

BTP jest nie tylko wskaźnikiem urazu mózgu lub niewydolności nerek. Biologiczną funkcją BTP jest katalizowanie konwersji prekursora prostanoidu - prostaglandyny H2 - do prostaglandyny D2 (PGD2) i jej metabolitu, 15-deoksy- $\Delta 12,14$-prostaglandyny J2 (15d-PGJ2), które regulują odpowiedź zapalną i syntezę białek macierzy pozakomórkowej. W modelu mysim wykazano, że PGD2 pochodzący z L-PGDS przyczynia się do postępu włóknienia nerek poprzez aktywację CRTH2 na limfocytach Th2 [17], a L-PGDS pochodzi z komórek nabłonka kanalików. Zablokowanie CRTH2 indukowanego PGD2 lub wyłączenie IL-4 i IL-13 łagodziło włóknienie nerek. Ponadto zarówno myszy ze znokautowanym genem L-PGDS, jak i CRTH2 wykazywały mniejsze włóknienie nerek, zmniejszony naciek 
The secondary product of L-PGDS, a PGD2 metabolite, is 15d-PGJ2, a PPAR- $\gamma$ agonist with potential therapeutic efficacy in eosinophil-induced diseases because it decreases the IgE amount, synthesis of IL-5, IL-33, IL-17 and IL-23 and eosinophil chemotaxis [10]. So PGD2 and its derivative exert the opposite effects. PGD2 binds CRTH2, activates Th2 lymphocytes and stimulates allergic reactions and tissue fibrosis $[5,17]$, whilst its metabolite $15 \mathrm{~d}-\mathrm{PGJ} 2$ activates PPAR- $\gamma$, abrogates proinflammatory PGD2-mediated effects [10] and inhibits TGF- $\beta$ signaling [18].

In our study we detected a significantly elevated level of BTP (L-PGDS) in SSc serum, both in limited and diffuse forms, but no correlation was found with inflammatory markers such as hs-CRP, extent of skin hardening evaluated as mRSS, disease duration and Raynaud's phenomenon onset time, type of autoantibodies, lung and esophagus involvement. We did not evaluate the concentrations of PGD2 driven cytokines, such as IL-4 and IL-13 in our patients, so we cannot say whether and how elevated BTP correlates with these cytokines in individuals with SSc. Based on the literature we can assume that already known elevated expression of these two pro-inflammatory and pro-fibrotic cytokines in SSc may partially result from the activated BTPPGD2-CRTH2 signaling pathway, but this statement requires further studies.

What is interesting from the SSc and pathological fibrosis point of view, is that 15d-PGJ2 inhibits TGF- $\beta$-mediated differentiation of human fibroblasts to myofibroblasts of normal and idiopathic pulmonary fibrotic fibroblasts by blocking Akt phosphorylation by a PPAR- $\gamma$-independent mechanism [18]. Also 15d-PGJ2 inhibits TGF- $\beta$-induced Akt phosphorylation via post-translational and post-transcriptional mechanisms. Inhibition of fibroblasts' transition into myofibroblasts by 15d-PGJ2 and other PPAR- $\gamma$ agonists is an interesting subject to explore. In our study, ILD in SSc did not correlate either positively or negatively with BTP, but we did not evaluate the amount of circulating 15d-PGJ2. Further studies with larger cohorts are needed to verify the possible relationship between BTP and ILD in SSc.

PGD2 interacts with aforementioned CRTH2 which belongs to the family of chemokine receptors and with the second receptor which is the prostanoid receptor DP1 $[8,17]$. Activation of the DP1 receptor by PGD2 has been shown to produce vasodilation and bronchodilation. The DP1 receptor is present on endothelial cells and the physiological action of PGD2 on DP1 includes not only dilation of blood vessels, but also increase in microvascular permeability, relaxation of smooth muscles, inhibition of platelet activation and eosinophil apoptosis, which is antagonistic to CRTH2 [8]. These vascular effects of pros- limfocytów Th2 do kory nerki i zmniejszoną produkcję profibrotycznych cytokin, takich jak IL-4 i IL-13 [17].

Wtórnym produktem L-PGDS, metabolitem PGD2, jest 15d-PGJ2, agonista PPAR- $\gamma$ o potencjalnej skuteczności terapeutycznej w chorobach mediowanych eozynofilami, ponieważ pod jego wpływem zmniejsza się ilość IgE, synteza IL-5, IL-33, IL-17 i IL-23 oraz chemotaksja eozynofilów [10]. PGD2 i jego pochodna 15d-PGJ2 powodują odwrotne skutki. PGD2 wiąże CRTH2, aktywuje limfocyty Th2, stymuluje reakcje alergiczne i włóknienie tkanek [5, 17], podczas gdy 15d-PGJ2 aktywuje PPAR- $\gamma$, znosi efekty prozapalne indukowane PGD2 [10] i hamuje przekaźnictwo TGF- $\beta$ [18].

W badaniu stwierdzono znacząco zwiększone stężenie BTP (L-PGDS) w surowicy pacjentów z SSc, zarówno w ograniczonej, jak i uogólnionej SSc, ale nie wykazano korelacji z markerem zapalnym hs-CRP, stopniem stwardnienia skóry ocenionym mRSS, czasem trwania choroby i objawu Raynauda, typem autoprzeciwciał, zajęciem płuc lub przełyku. Nie badano stężeń cytokin indukowanych PGD2, takich jak IL-4 i IL-13, dlatego nie można stwierdzić, czy i jak zwiększone stężenie BTP wpływa na ich stężenie u poszczególnych pacjentów z SSc. Na podstawie piśmiennictwa można założyć, że znacznie w badaniach zwiększona ekspresja tych dwóch cytokin stymulujących włóknienie w SSc może częściowo wynikać z aktywowanego szlaku sygnałowego BTP-PGD2-CRTH2, ale ta teza wymaga dalszych badań.

Z punktu widzenia SSc i patologicznego włóknienia interesujący jest fakt, że 15d-PGJ2 hamuje zależne od TGF- $\beta$ różnicowanie ludzkich fibroblastów do miofibroblastów normalnych oraz fibroblastów idiopatycznego włóknienia płuc poprzez blokowanie fosforylacji Akt w mechanizmie niezależnym od PPAR- $\gamma$ [18]. Również 15d-PGJ2 hamuje indukowaną przez TGF- $\beta$ fosforylację Akt w mechanizmach potranslacyjnych i potranskrypcyjnych. Hamowanie przemiany fibroblastów w miofibroblasty przez 15d-PGJ2 i innych agonistów PPAR- $\gamma$ jest ciekawym zjawiskiem, wartym wyjaśnienia w chorobach z patologicznym włóknieniem. W naszym badaniu ILD w SSc nie korelowała w żaden sposób z BTP, ale nie ocenialiśmy ilości krążącego 15d-PGJ2. Potrzebne są dalsze badania z większą liczbą pacjentów, aby wyjaśnić potencjalny związek między BTP a ILD w SSc.

PGD2 oddziałuje z dwoma receptorami - wyżej wymienionym CRTH2, który należy do rodziny receptorów chemokin, i receptorem prostanoidowym DP1 [8, 17]. Wykazano, że aktywacja receptora DP1 przez PGD2 powoduje rozszerzenie naczyń i oskrzeli. Receptor DP1 jest obecny na komórkach śródbłonka, a fizjologiczne działanie PGD2 na DP1 obejmuje nie tylko rozszerzenie naczyń krwionośnych, lecz także zwiększenie ich przepuszczalności, rozkurcz mięśni gładkich, zahamowanie aktywacji płytek i apopto- 
taglandins and prostanoids mediated by DP1 have a great importance in SSc due to impairment of vascular relaxation and defective nitric oxide production [19]. Therefore vasoactive therapy in SSc is the mainstay treatment option in many recommendations to reduce endothelial cell injury and its complications such as inflammation, tissue hypoxia and ulceration [20]. Vasoactive therapy includes e.g. intravenous prostanoids and prostacyclin analogs [7, 21]. Prostaglandins are rapidly metabolized in vivo, which is usually associated with a significant decrease in their biological activity; therefore their pharmacological analogs are used.

BTP activates PGD2, which may show antagonistic effects: one unfavorable for SSc connected with CRTH2 activation, immune stimulation, and IL- 4 and IL-13 synthesis, and the second beneficial for SSc connected with DP1 receptor interaction leading to vasodilation and smooth muscle relaxation. The indirect confirmation of the prevailed BTP dependent activation of CRTH2 is elevated IL-4 and IL-13 expression in SSc, whilst the efficacy of prostanoid treatment in SSc improving RP, preventing and healing digital ulcerations in SSc confirms defective vascular relaxation mechanism, which may be dependent on the deficient interaction of PGD2 with DP1.

\section{CONCLUSIONS}

This is the first study showing significantly elevated serum BTP (lipocalin-type PGD2 synthase) in SSc in comparison to healthy controls. This difference cannot be explained by renal insufficiency, since SSc patients selected for the study were thoroughly checked for renal disease and presented GFR within the normal range. The result of significantly elevated BTP in SSc at $p<0.001$ may indicate the role of L-PGDS in disease pathogenesis, since a BTP-dependent effect can be involved in three main features of SSc - inflammation/autoimmunity, vasocontraction and fibrosis. No association betwen BTP and hs-CRP, autoantibody presence, extent of skin fibrosis, organ involvement or disease duration has been found. BTP has shown a significant correlation with vascular involvement estimated by the presence of digital ulcerations and/or pitting scars on finger tips indicating the impaired BTP effect in the regulation of the vascular process in SSc.

This first BTP study in SSc should be interpreted in light of its limitations. The group of patients was small and the effects directly related to BTP were not evaluated, but significantly elevated concentration of BTP in SSc may indicate its role in the disease pathogenesis. Further studies with greater number of patients are required to fully establish prognostic and diagnostic significance of BTP in SSc. zę eozynofilów, co jest przeciwstawne do CRTH2 [8]. Wpływ prostaglandyn i prostanoidów na naczynia za pośrednictwem DP1 ma ogromne znaczenie w SSc z powodu upośledzonej relaksacji naczyń i wytwarzania tlenku azotu [19]. Dlatego w wielu rekomendacjach dotyczących SSc terapia rozszerzająca naczynia jest podstawowym postępowaniem w celu ograniczenia uszkodzenia komórek śródbłonka i powikłań naczyniowych, takich jak zapalenie, niedotlenienie tkanek i owrzodzenia [20]. Terapia naczyniowa obejmuje dożylne prostanoidy i analogi prostacykliny [7, 21]. Prostaglandyny są szybko metabolizowane in vivo, co wiąże się ze znacznym zmniejszeniem ich aktywności biologicznej, dlatego stosuje się ich analogi farmakologiczne.

BTP stymuluje PGD2, która ma antagonistyczne działanie: jedno niekorzystne dla SSc związane z aktywacją CRTH2, stymulacją immunologiczną oraz syntezą IL-4 i IL-13, a drugie korzystne dla SSc związane z oddziaływaniem na receptor DP1 prowadzące do rozszerzenia naczyń i rozluźnienia mięśni gładkich. Pośrednim potwierdzeniem przeważającej aktywacji CRTH2 zależnej od BTP jest podwyższona ekspresja IL-4 i IL-13 w SSc, podczas gdy skuteczność leczenia prostanoidami w SSc, które zmniejsza objaw Raynauda, goi owrzodzenia i zapobiega ich powstawaniu, potwierdza upośledzony mechanizm relaksacji naczyń, być może zależny od deficytu interakcji PGD2 z DP1.

\section{WNIOSKI}

Przedstawiamy pierwsze badanie, które wykazuje znamiennie zwiększone stężenie BTP (L-PGDS) w surowicy pacjentów z SSc w porównaniu z grupą kontrolną osób zdrowych. Różnicy tej nie można tłumaczyć niewydolnością nerek. Zwiększone stężenie BTP w SSc przy $p<0,001$ może świadczyć o jego roli w patogenezie choroby, ponieważ zależny od BTP efekt przekłada się na trzy podstawowe zjawiska w SSc: zapalenie lub autoimmunizację, skurcz naczyń i włóknienie tkanek. Nie stwierdzono związku między BTP a hs-CRP, obecnością autoprzeciwciał, stopniem włóknienia skóry, zajęciem narządów lub czasem trwania choroby. Stężenie BTP wykazało istotną korelację z zajęciem naczyń ocenianym na palcach rąk (obecność owrzodzeń i zanikowych blizenek), wskazującym na upośledzony efekt BTP w regulacji procesu naczyniowego w SSc.

Jest to pierwsze badanie stężenia BTP u pacjentów z SSc, dlatego przy interpretacji wyników należy uwzględnić jego ograniczenia. Grupa pacjentów była mała, a efekty wynikające bezpośrednio z BTP nie były badane. Znacząco zwiększone stężenie BTP w SSc może odgrywać rolę w patogenezie choroby. Potrzebne są dalsze badania obejmujące większą liczbę pacjentów w celu oceny znaczenia klinicznego i prognostycznego BTP w SSc. 


\section{ACKNOWLEDGMENTS}

This project was funded by grant 1M4/NM1/18

from the Medical University of Warsaw.

\section{CONFLICT OF INTEREST}

The authors declare no conflict of interest.

\section{PODZIĘKOWANIA}

Projekt badawczy finansowano z dotacji 1M4/ NM1/18 z Uniwersytetu Medycznego w Warszawie.

\section{KONFLIKT INTERESÓW}

Autorzy nie zgłaszają konfliktu interesów.

\section{References}

\section{Piśmiennictwo}

1. Allanore Y., Simms R., Distler O., Trojanowska M., Pope J., Denton C.P., et al.: Systemic sclerosis. Nat Rev Dis Primers 2015, 1 , 15002.

2. Tomčík M., Arima K., Hulejová H., Kuklová M., Filková M., Braun M., et al.: Adiponectin relation to skin changes and dyslipidemia in systemic sclerosis. Cytokine 2012, 58, 165-168.

3. Asano Y.: Epigenetic suppression of Fli1, a potential predisposing factor in the pathogenesis of systemic sclerosis. Int $\mathrm{J}$ Biochem Cell Biol 2015, 67, 86-91.

4. Stochmal A., Czuwara J., Trojanowska M., Rudnicka L.: Antinuclear antibodies in systemic sclerosis: an update. Clin Rev Allergy Immunol 2019 Doi: 10.1007/s12016-018-8718-8.

5. Xue L., Gyles S.L., Wettey F.R., Gazi L., Townsend E., Hunter M.G., et al.: Prostaglandin D2 causes preferential induction of proinflammatory Th2 cytokine production through an action on chemoattractant receptor-like molecule expressed on Th2 cells. J Immunol 2005, 175, 6531-6536.

6. Gluais P., Lonchampt M., Morrow J.D., Vanhoutte P.M., Feletou M.: Acetylcholine-induced endothelium-dependent contractions in the SHR aorta: the Janus face of prostacyclin. Br J Pharmacol 2005, 146, 834-845.

7. Volkmann E.R., Varga J.: Emerging targets of disease-modifying therapy for systemic sclerosis. Nat Rev Rheumatol 2019, 15, 208-224.

8. Kupczyk M., Kuna P.: Targeting the PGD2/CRTH2/DP1 signaling pathway in asthma and allergic disease: current status and future perspectives. Drugs 2017, 77, 1281-1294.

9. Olsson J.E.: Human beta-trace in normal and pathological cns tissues, genital organs and body fluids. In: Recent Advances in Prostaglandin, Thromboxane, and Leukotriene Research. H. Sinzinger, B. Samuelsson, J.R. Vane, R. Paoletti, P. Ramwell, P.Y.K.Wong (eds). Springer, Boston 1997, 351-354.

10. Farnesi-de-Assuncao T.S., Alves C.F., Carregaro V., de Oliveira J.R., da Silva C.A., Cheraim A.B., et al.: PPAR-gamma agonists, mainly 15d-PGJ(2), reduce eosinophil recruitment following allergen challenge. Cell Immunol 2012, 273, 23-29.

11. Bacci M.R., da Costa Aguiar Alves B., Cavallari M.R., Azzalis L.A., de Rozier-Alves R.M., Perez M.M., et al.: Urinary beta-trace protein gene expression analysis in type 2 diabetes mellitus patients. Einstein (Sao Paulo) 2017, 15, 441-444.

12. Murakami Y., Takahashi K., Hoshi K., Ito H., Kanno M., Saito K., et al.: Spontaneous intracranial hypotension is diagnosed by a combination of lipocalin-type prostaglandin D synthase and brain-type transferrin in cerebrospinal fluid. Biochim Biophys Acta Gen Subj 2018, 1862, 1835-1842.

13. Dajak M., Ignjatović S., Stojimirović B., Gajić S., Majkić-Singh N.: Evaluation of renal damage by urinary beta-trace protein in patients with chronic kidney disease. Clin Lab 2011, 57, 29-36.

14. Khosravi N.: Serum beta-trace protein for assessment of kidney function in neonates. Iran J Kidney Dis 2018, 12, 11-13.

15. van den Hoogen F., Khanna D., Fransen J., Johnson S.R., Baron M., Tyndall A., et al.: 2013 classification criteria for systemic sclerosis: an American College of Rheumatology/European League against Rheumatism Collaborative Initiative. Ann Rheum Dis 2013, 72, 1747-1755.

16. Chia J.J., Zhu T., Chyou S., Dasoveanu D.C., Carballo C., Tian S., et al.: Dendritic cells maintain dermal adipose-derived stromal cells in skin fibrosis. J Clin Invest 2016, 126, 4331-4345.

17. Ito H., Yan X., Nagata N., Aritake K., Katsumata Y., Matsuhashi T., et al.: PGD2-CRTH2 pathway promotes tubulointerstitial fibrosis. J Am Soc Nephrol 2012, 23, 1797-1809.

18. Kulkarni A.A., Thatcher T.H., Olsen K.C., Maggirwar S.B., Phipps R.P., Sime P.J.: PPAR-gamma ligands repress TGFbeta-induced myofibroblast differentiation by targeting the PI3K/Akt pathway: implications for therapy of fibrosis. PLoS One 2011, 6, e15909.

19. Michalska-Jakubus M., Kowal M., Adamczyk M., Krasowska D.: Anti-endothelial cell antibodies do not correlate with disease activity in systemic sclerosis. Adv Dermatol Allergol 2018, 35, 185-191.

20. Kowal-Bielecka O., Fransen J., Avouac J., Becker M., Kulak A., Allanore Y., et al.: Update of EULAR recommendations for the treatment of systemic sclerosis. Ann Rheum Dis 2017, 76, 1327-1339.

21. Moinzadeh P., Riemekasten G., Siegert E., Fierlbeck G., Henes J., Blank N., et al. Vasoactive therapy in systemic sclerosis: real-life therapeutic practice in more than 3000 patients. J Rheumatol 2016, 43, 66-74.

Received: 20.01 .2019

Accepted: 24.04.2019

Otrzymano: 20.01.2019 r.

Zaakceptowano: 24.04.2019 r.

How to cite this article

Żółkiewicz J., Stochmal A., Zaremba M., Rudnicka L., Czuwara J.: Serum concentration of beta-trace protein (BTP) as a potential biomarker of systemic sclerosis. Dermatol Rev/Przegl Dermatol 2019, 106, 173-184. DOI: https://doi.org/10.5114/dr.2019.85575. 